\title{
Technique
}

\section{The collection of pancreatic fluid for cytodiagnosis using a duodenoscope}

\author{
A. R. W. HATFIELD, R. WHITTAKER, AND D. D. GIBBS \\ From Good Hope District General Hospital, Sutton \\ Coldfield, Warwickshire
}

The established way of collecting pancreatic fluid for cytological examination has been by means of a double-lumen tube (Lemon and Byrnes, 1949). Although a method of rapid intubation has been described (Raskin, Wenger, Sklar, Pleticka, and Yarema, 1958), the procedure remains time consuming and also produces fluid which contains cells exfoliated from a variety of other sources in the upper gastrointestinal tract (Nieburgs, Dreiling, Rubio, and Reisman, 1962; Butler, B. 1972). Cells collected in this conventional manner often show degenerate features due to rapid enzymatic digestion. Wenger and Raskin (1958) used a maximal secretin stimulus to improve the yield of pancreatic cells in duodenal aspirates.

Since the technique of endoscopic cannulation of the papilla of Vater has been introduced in this country (Cotton, Salmon, Blumgart, Burwood, Davies, Lawrie, Pierie, and Read, 1972; Cotton, 1972), a method of obtaining relatively uncontaminated pancreatic fluid has become available.

\section{Method of Collection}

Patients were examined endoscopically in the fasting state after the administration of atropine and diazepam. Jaundiced patients were Australia antigen negative. A side-viewing duodenoscope, Olympus model JF-B, was used, through which a sterile Teflon cannula was passed (external diameter $1.5 \mathrm{~mm}$ ). Intravenous injection of butyl-N-hyoscine hydrobromide (Buscopan) was used to inhibit duodenal peristalsis. Secretin (BP), 1 unit/kg body weight, was given intravenously, and in most patients caused a visible emission of pancreatic fluid from the papilla of Vater within two minutes.

Insertion of the cannula tip into the papilla, together with gentle negative pressure usingl a $20 \mathrm{ml}$ syringe, produced small volumes of pancreatic fluid.

Five ml aliquots of fluid were collected in sterile

Present address: Northwick Park Hospital and Clinical Research Centre, Harrow, Middlesex

Received for publication 12 December 1973. universal containers and an equal volume of Cytofix was added immediately. By using a cytocentrifuge (Shandon Southern Cytospin) cells were directly deposited on the glass slides, forming a $5 \mathrm{~mm}$ diameter circle. After routine staining the cells were available for screening in a compact area.

\section{Results}

Ten patients were studied. In six of these, pancreatic and fluid could be aspirated directly from within the papilla of Vater. In the other four patients, fluid was easily collected as it issued from the papilla or from the pools which formed in its neighbourhood.

Time spent in aspirating fluid varied between 15 and 20 minutes and the duration of the complete procedure never exceeded 40 minutes. In two patients the volume of fluid was small $(5 \mathrm{ml})$ but in the remainder the volumes ranged from 15 to $50 \mathrm{ml}$. In nine of the 10 patients cells derived from the pancreatic duct were plentiful and well preserved (fig 1). In the remaining case duct cells were seen but in small numbers. Acinar cells were identified from one patient.

In most specimens there were some polymorphs and macrophages, but cells from gastric or duodenal epithelium were not obvious. In two patients it was possible to detect cells which were probably derived from the biliary tract.

Six patients had a clinical diagnosis of inflammatory pancreatic disease and in fluid from all these patients normal duct cells were present, without suspicion of malignancy. The other four patients were suspected cases of pancreatic neoplasm, later proven by various means. In the pancreatic fluid collected from two of these patients neoplastic cells were identified (fig 2 ).

\section{Discussion}

To the investigator familiar with the technique of endoscopic retrograde cholangiopancreatography (ERCP) the procedure described here for obtaining pancreatic fluid is rapid and simple. Although the volume of fluid obtained is small there is a satisfactory yield of cells which show little degeneration. There was no apparent deterioration in cell preservation when fluid was collected from the surface of the papilla rather than within the duct. 


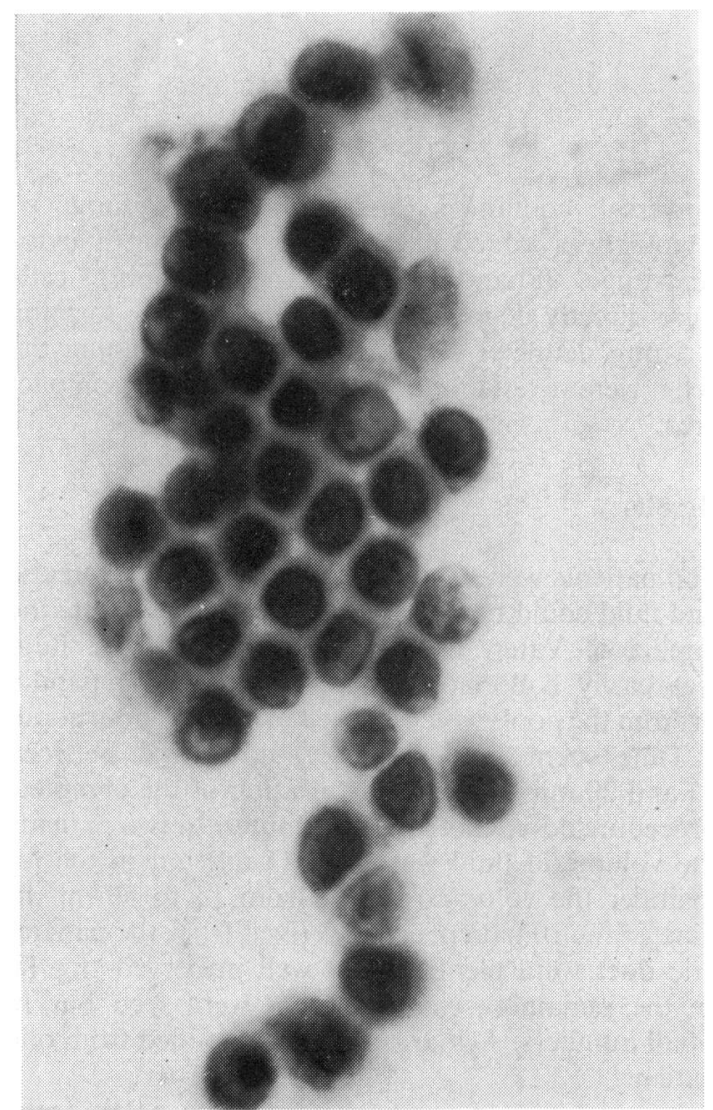

Fig 1 Normal pancreatic duct cell.

We feel that this procedure should be carried out independently from ERCP. Kozu found that there was distortion of pancreatic cells collected as contrast media drained from the pancreatic duct system (Kozu, Oi, and Takemoto, 1972). Endoscopic retrograde cholangiopancreatography is already known to cause amylasaemia and occasionally pacreatitis (Kasugai, Kuno, Kizu, Kobayashi, and Hattori, 1972), and secretin stimulation could increase these risks. Two patients in this series experienced abdominal pain after the injection of secretin and in one of them serum amylase rose to over 2000 units on the following day. Both these patients were later shown to have an obstruction in the main pancreatic duct due to neoplasm.

\section{Conclusion}

The technique described allows the collection of pancreatic fluid to be carried out simply and quickly. Fluid obtained in this way has the advantage of

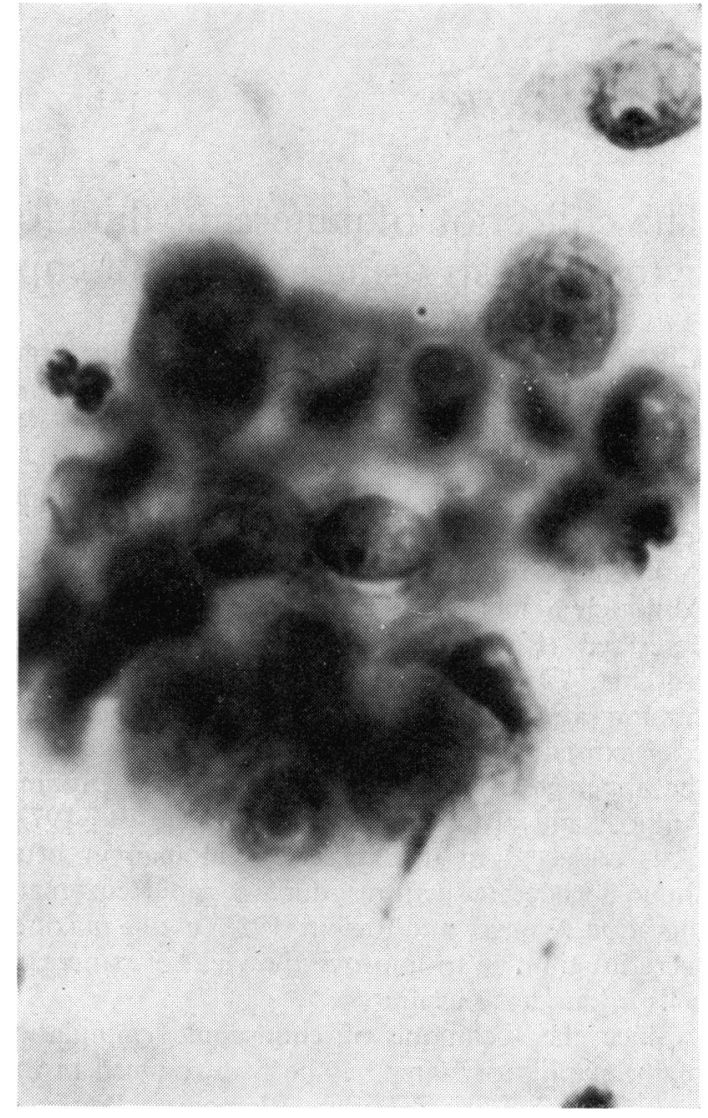

Fig 2 Clump of adenocarcinoma cells.

containing a plentiful supply of well preserved duct cells and is comparatively free from cells derived from other sources. The procedure is not likely to find favour for the routine screening of patients, but it has potential when used in conjunction with other pancreatic investigations, especially endoscopic retrograde cholangiopancreatography.

Further work will show whether the diagnostic value of this method matches that already reported with more conventional methods of collecting pancreatic fluid for cytology.

\section{References}

Butler, B. (1972). Pancreatic cytology. Clin. Gastroent., 1, 53. Cotton, P. B. (1972). Cannulation of the papilla of Vater by endoscopy and retrograde cholangiopancreatography (ERCP). Gut, 13, 1014-1025.

Cotton, P. B., Salmon, P. R., Blumgart, L. H., Burwood, R. J., Davies, G. T., Lawrie, B. W., Pierce, J. W., and Read, A. E. (1972). Cannulation of papilla of Vater via fiber-duodenoscope: assessment of retrograde cholangiopancreatography in 60 patients. Lancet, $1,53-58$. 
Kasugai, T., Kuno, N., Kizu, M., Kobayashi, S., and Hattori, K. (1972). Endoscopic pancreatography. II. The pathological endoscopic pancreatogram. Gastroenterology, 63, 227-234.

Kozu, T., Oi, I., and Takemoto, T. (1972). The cytology of the intrapancreatic juice taken by duodenoscope cannulation into the duodenal papilla. In Proceedings of the 2nd European Congress. Congress of Digestive Endoscopy, Paris.

Lemon, H. M., and Byrnes, W. W. (1949). Cancer of the biliary tract and pancreas: diagnosis from cytology of duodenal aspirations. J. Amer. med. Ass., 141, 254-257.

Nieburgs, H. E., Dreiling, D. A., Rubio, C., Reisman, H. (1962).
The morphology of cells in duodenal-drainage smears: histologic origin and pathologic significance. Amer. J. dig. Dis., 7, 489-505.

Raskin, H. F., Wenger, J., Sklar, M., Pletricka, S., and Yarema, W. (1958). The diagnosis of cancer of the pancreas, biliary tract, and duodenum by combined cytologic and secretory methods. 1. Exfoliative Cytology and a description of a rapid method of duodenal intubation. Gastroenterology, 34, 996-1008.

Wenger, J., and Raskin, H. F. (1958). The diagnosis of cancer of the pancreas, biliary tract, and duodenum by combined cytologic and secretory methods. 11 . The secretin test. Gastroenterology, 34, 1009-1017.

\section{The March 1974 Issue}

\section{THE MARCH 1974 ISSUE CONTAINS THE FOLLOWING PAPERS}

Liver structure and function in cholelithiasis: Effect of chenodeoxycholicacid G. D. BELL, H. Y. I. MOK, M. THWE, G. M. MURPHY, K. HENRY, AND R. H. DOWLING

Factors influencing duodenal trypsin levels following a standard test meal as a test of pancreatic function I. J. ZEITLIN AND W. SIRCUS

Medium chain triglycerides and hepatic encephalopathy M. HILARY MORGAN, C. H. BOLTON, J. S. MORRIS, AND A. E. READ

Fibrosing alveolitis and treatment with sulphasalazine DEWI DAVIES AND ANDREW MacFARLANE

Evaluation of colloidal bismuth (De-Nol) in the treatment of duodenal ulcer employing endoscopic selection and follow up P. R. SALMON, P. BROWN, R. WILLIAMS, AND A. E. READ

Gastric clearance of serum albumin in normal man and in certain gastroduodenal disorders $\mathbf{A}$. BRASSINNE

The dumping syndrome and the hydrogen ion concentration of the gastric contents JAMES $P$. $S$. THOMSON, R. C. G. RUSSELL, M. HOBSLEY, AND L. P. LE QUESNE
Intestinal streaming patterns in cholerrhoeic enteropathy and diverticular disease J. M. FINDLAY, W. D. MITCHELL, M. A. EASTWOOD, A. J. B. ANDERSON, AND A. N. SMITH

The immune competence of patients with inflammatory bowel disease P. M. BOLTON, SUSAN L. JAMES, R. G. NEWCOMBE, R. H. WHITEHEAD, AND L. E. HUGHES

Sites of competition in the selective hepatic uptake of rifamycin-SV, flavaspidic acid, bilirubin, and bromsulphthalein S. KENWRIGHT AND A. J. LEVI

\section{Technique}

A method for rapid placing of small intestinal perfusion tubes MILTON G. SCHMITT, JR, CAROL M. WOOD, AND KONRAD H. SOERGEL

\section{Progress report}

Small bowel resection and gastric acid hypersecretion BRIAN BUXTON

\section{Progress report}

Some factors influencing absorption rates of the digestion products of protein and carbohydrate from the proximal jejunum of man and their possible nutritional implications G. C. COOK

Notes and activities

Notes on books

Copies are still available and may be obtained from the PUBLISHING MANAGER, BRITISH MEDICAL ASSOCIATION, TAVISTOCK SQUARE, LONDON WC1H 9JR, price $87 \frac{1}{2} \mathrm{p}$ 